\title{
Effect of Gamma-Irradiation or/and Extrusion on the Nutritional Value of Soy Flour
}

Refaat G. Hamza ${ }^{*}$, Safaa Afifi', Abdel-Rahman B. Abdel-Ghaffar ${ }^{2}$ and Ibrahim H. Borai ${ }^{2}$

${ }^{1}$ Food Irradiation Research Department, National Centre for Radiation Research and Technology (NCRRT), Atomic Energy Authority, Cairo, Egypt ${ }^{2}$ Biochemistry Department, Faculty of Science, Ain Shams University, Cairo, Egypt

\begin{abstract}
Although soybean is rich with high amount of protein, phenolic compounds and other bioactive nutrients, their bioavailability and utilization by either humans or animals are relatively low due to the presence of high proportions of various antinutrients. Therefore, this study was assessed to use gamma irradiation or/and extrusion for inactivation or removal of certain antinutritional factors as well as study the effect of these processing method on the nutritional value of soy flour (the simplest form of soy protein). Analyses included proximate composition, the level of total phenols and levels of antinutrients (phytic acid, tannins and trypsin inhibitors) of raw and processed soy flour. In addition, amino acid contents were analyzed by using high performance amino acid analyzer-Biochrom 20 , gas chromatography was used for analysis of fatty acids as well as phenolic compounds were determined by high performance liquid chromatography. The results showed that moisture, crude protein, crude fat, crude fiber, and ash were unchanged by the irradiation $(5$ and $10 \mathrm{KGy}$ ) or/and extrusion except the moisture content was decreased by extrusion. y-irradiation or/and extrusion processing significantly reduced the levels of phytic acid, tannins, and trypsin inhibitor while the total phenols was increased relative to unprocessed control samples. All essential amino acids, fatty acids and phenolic compound were changed by different values. From these results, it could be possible to demonstrate the benefits of $y$-irradiation or/ and extrusion processing on the nutritional properties of soy flour by reducing its antinutritional contents and improving some of functional nutrients.
\end{abstract}

Keywords: Gamma-irradiation; Extrusion; Soy flour; Antinutritional factors.

\section{Introduction}

Legumes are consumed in large quantities because they are considered as poor man's meat, cheap and valuable potential source of complex carbohydrates $50-60 \%$, protein and dietary fiber; contribute significant amounts of vitamins and minerals, and high energy value $[1,2]$. Protein contents in legume grains range from $17 \%$ to $40 \%$, contrasting with $7-13 \%$ of cereals, and being equal to the protein contents of meats $18-25 \%$ [3].

Soybeans (Glycine max) is a species of legumes which are becoming an important economic crop as a major source of protein, energy, polyunsaturated fats, fiber, vitamins, minerals, and other nutrients [4-6]. Its low cost and its useful health benefits are improving its use even to animal or human nutrition in different groups, in order to reduce risk factors for chronic diseases like diabetes mellitus, cancer, cardiovascular disease, osteoporosis and others [7]. On the other hand, the nutritive quality and digestibility of soy protein in both human and animals are restricted by the presence of antinutritional factors such as phytic acid, tannins and trypsin inhibitors [8].

In order to inactivate or reduce the antinutritional substances, various conventional, simple processing methods have been used such as dry heating, roasting, boiling, soaking in water $[9,10]$. However, none of these methods is able to completely remove all the detected antinutrients that are present in seeds, grains or feed materials. Gamma irradiation treatment and extrusion cooking of legumes may be one of the possible alternative and additional processing techniques for reducing antinutrients and improving the nutritive quality of legumes [11-13].

Soybeans irradiated at a dose level of $10 \mathrm{KGy}$, retained their normal levels of moisture, crude protein, fat and ash. This dose level does not result in the denaturation of protein, and does not affect the nitrogen containing components of the food materials $[14,15]$. Also, gammairradiation induced enhancement of isoflavones, phenols, anthocyanin and antioxidant properties of different seed coat colored soybean genotypes has been recently reported [16].

In addition, extrusion cooking application to legume processing has developed quickly during the last decade, and can now be considered as a technology of its own right. It would allow reduction of antinutritional factors and it not only improves digestibility [17] but also improves nutrient bioavailability [13] at a cost lower than other heating systems (baking, autoclaving, etc.). Also, extrusion processing for soybeans can convert them to a high quality food product [18].

This study was designed to assess the effects of gamma irradiation or/and extrusion processing on the anti-nutritional factors, amino acid content, fatty acids and phenolic compound of soy flour.

\section{Material and Methods}

\section{Material}

Freshly dried soybean seeds were obtained from the Agriculture Research Institute, Ministry of Agriculture and Land Reclamation, Giza, Egypt. Seeds were sorted by discarding damaged and immature ones. They were stored in air-tight containers at room temperature (25 $\pm 1^{\circ} \mathrm{C}$ ) prior to further use.

*Corresponding author: Refaat Galal Hamza, Assistant Professor of Biochemistry, Department of food irradiation, Atomic Energy Authority, 3 Ahmed El Zomor St., El Zohour District, 8th District, Nasr City, Cairo, Egypt, E-mail: Refaat.galal2009@yahoo.com

Received July 06, 2012; Accepted September 20, 2012; Published September 24, 2012

Citation: Hamza RG, Afifi S, Abdel-Ghaffar ARB, Borai IH (2012) Effect of GammaIrradiation or/and Extrusion on the Nutritional Value of Soy Flour. Biochem Anal Biochem 1:118. doi:10.4172/2161-1009.1000118

Copyright: (c) 2012 Hamza RG, et al. This is an open-access article distributed under the terms of the Creative Commons Attribution License, which permits unrestricted use, distribution, and reproduction in any medium, provided the original author and source are credited. 


\section{Seeds treatment}

Gamma irradiation treatment: Soybean seeds were packed in polyethylene bags, and sealed by heat. They were treated with 5 and 10 $\mathrm{KGy}$, delivered at a dose rate of $4.75 \mathrm{KGy} / \mathrm{h}$. The facility used was the Indian Gamma Chamber $400 \mathrm{~A},{ }^{60} \mathrm{Co}$ facility at the National Center for Radiation Research and Technology (NCRRT) - Nasr City, Cairo, Egypt.

Heat processing (Extrusion): The whole soybean seeds were cleaned, dehulled, ground to coarse particles, and then extruded by single screw extruder with three zones at the Soy processing unit, Food Technology Research Institute, Agriculture Research Center, Giza, Egypt. The heat treatment rise gradually through extruder zones for short time.

Combination of $\gamma$-irradiation and extrusion: Soybean seeds were packed in polyethylene bags, and sealed by heat. They were subjected to ambient temperature to gamma irradiation at dose levels of ( 5 and $10 \mathrm{KGy}$ ) and dose rate of $4.75 \mathrm{KGy} / \mathrm{h}$, then followed by heat processing at high temperature (by gradual increase in temperature through extruder zones ) for short time.

\section{Preparation of soy flour}

Either raw or treated soy flour was prepared by cleaning, dehulling the raw and treated seeds. Then the dehulled seeds were grind to obtain the flour.

\section{Determination of chemical composition of raw and treated soy flour}

Determination of moisture, ash, crude protein, total crude lipid and crude fiber content were determined according to the method of A.O.A.C. [19].

\section{Determination of amino acid composition of raw and treated soy flour}

This analysis was performed at the central laboratories of National Center for Radiation Researches and Technology (NCRRT) at Nasr City-Cairo, using high performance amino acid analyzer-Biochrom 20 (auto sampler version) Pharmacia Biotech.

\section{Procedure}

\section{Hydrolysis procedure}

Dried and defatted samples were weighed in the screw-capped tubes $(50-100 \mathrm{mg})$ and $5 \mathrm{ml}$ of HCL $(6.0 \mathrm{~N})$ was added to each tube. The tubes were attached to a system; which allows the connection of nitrogen and vacuum lines without disturbing the sample. The tubes were placed in an oven at $110^{\circ} \mathrm{C}$ for 24 hours [20]. The tubes were then opened and the contents of each tube was filtered and evaporated until dryness in a rotary evaporator. A suitable volume of $0.2 \mathrm{M}$ sodium citrate buffer ( $\mathrm{pH}$ 2.2) was added to dissolve the contents of each dried film of the hydrolyzed sample followed by ultrafiltration using a $0.2 \mu \mathrm{m}$ membrane filter [21]. Hydrolyzed sample solution was introduced to the column.

\section{Elution buffers and detection reagent}

Amino acids were achieved using buffers with different $\mathrm{pH}$ and molarities. In general, higher the $\mathrm{pH}$ and molarities, the faster elute amino acids. Three citrate buffers were used to elute 16 amino acids, buffer 1(0.2 M, pH 3.20) and buffer $2(0.2 \mathrm{M}, \mathrm{pH} 4.25)$ elute the acidic and neutral amino acids while buffer $3(0.2 \mathrm{M}, \mathrm{pH} 6.45)$ elute the basic amino acids.
In addition, a loading dilution citrate buffer $(0.2 \mathrm{M}, \mathrm{pH} 2.2)$ and a column-regeneration solution $(0.4 \mathrm{M} \mathrm{NaOH})$ was used. All buffers and $\mathrm{NaOH}$ solution were Pharmacia Biotech Chemicals. Ninhydrin detection reagent was used which consisted of ultra solve $(2.0 \mathrm{~L})$, ninhydrin (20 g) and hydrindantin (1.6 g). All these items were Pharmacia Biotech Chemicals.

\section{Analytical conditions}

Amino acid analyzer equipped with stainless steel column (200x4.6 $\mathrm{mm})$ packed with altropac $8(8 \mu \mathrm{m} \pm 0.5 \mu \mathrm{m})$ cation exchange resin. Application of the sample is followed by stepwise elution with the aforementioned 3 buffers resolved 17 amino acids. The following program was used for the separation and detection of the amino acids:

Buffer 1 was pumped for 9 minutes followed by buffer 2 for 12 minutes and buffer 3 for 17 minutes. The column was regenerated using $0.4 \mathrm{M} \mathrm{NaOH}$ for 4 minutes followed by equilibration in buffer, for $16 \mathrm{~min}$. The column was initially heated at $53^{\circ} \mathrm{C}$ for 9 minutes. The temperature was changed to $58^{\circ} \mathrm{C}$ for $13 \mathrm{~min}$ then changed to $95^{\circ} \mathrm{C}$ for 24 minutes, finally cooled down to $53^{\circ} \mathrm{C}$ for the remainder of the cycle (12 minutes) The cycle time from injection to injection was 58 minutes.

The flow rate was $25 \mathrm{ml} / \mathrm{hr}$ for ninhydrin reagent and $35 \mathrm{ml} / \mathrm{hr}$ for the buffers. The reaction between the amino acids and ninhydrin occurred at $135^{\circ} \mathrm{C}$ in a $10 \mathrm{ml}$ PTFE reaction coil ( $0.3 \mathrm{~mm}$ I.D) immersed in silicon oil. Detection was performed at two wavelengths (570 and $440 \mathrm{~nm}$ ). The data of each chromatogram was analyzed by EZ. ChromChromatography Data system Tutorial and user's Guide- Version 6.7.

\section{Determination of fatty acid composition of raw and treated} soy flour

The Fatty Acids (FA) were analyzed using Chromatograph-Mass at NCRRT. Separation was obtained by using a selective detector instrument "GC -MS" type HP, 6890 series, equipped with a flame ionization detector and innowax-cross linked polyethylene glycol fused silica column was used for characterization of fatty acids.

\section{Determination of total phenols of raw and treated soy flour}

Total phenolic contents were measured by using the Folin Ciocalteau colorimetric method [22].

\section{Determination of phenolic compounds of raw and treated soy flour}

Grounded dry powder of soy flour ( $10 \mathrm{~g})$ was weighed into a test tube. A total of $100 \mathrm{ml}$ of $80 \%$ aqueous methanol was added, and the suspension was stirred slightly. Tubes were sonificated twice for 15 min and one left at room temperature $\left(20^{\circ} \mathrm{C}\right)$ for $24 \mathrm{~h}$. The extract was centrifuged for $10 \mathrm{~min}(10 \mathrm{~min}, 1500 \mathrm{xg})$, and supernatants were filtered through a $0.2 \mu \mathrm{m}$ millipore membrane filter then $1-3 \mathrm{ml}$ was collected in avail for the HPLC analysis of phenolic compounds.

Phenolic standard were determined by HPLC according to the method of Goupy et al. [23]. Phenolic compounds of soy flour were analyzed at the Agriculture Research Center, Giza, Egypt by using HPLC Hewlett Packard (series 1050) equipped with autosampling injector, solvent degasser, Ultraviolet (UV) detector set at 280 nm and quarter HP pump (series 1050). The column temperature was maintained at $35^{\circ} \mathrm{C}$. Gradient separation was carried out with methanol and acetonitrile as a mobile phase at flow rate of $1 \mathrm{ml} / \mathrm{min}$. The Phenolic standard from sigma Co. were dissolved in a mobile phase and injected into HPLC. Retention time and peak area were used 
Citation: Hamza RG, Afifi S, Abdel-Ghaffar ARB, Borai IH (2012) Effect of Gamma-Irradiation or/and Extrusion on the Nutritional Value of Soy Flour. Biochem Anal Biochem 1:118. doi:10.4172/2161-1009.1000118

to calculate phenolic compounds concentration by the data analysis of Hewlett Packard software.

\section{Determination of antinutritional factors of raw and treated soy flour}

Tannins content were measured by using the vanillin- $\mathrm{HCl}$ method [24], phytic acid content was determined by the method described of Wheeler and Ferrel [25], as well as trypsin inhibitors were determined by using benzoyl-DL-arginine-p-nitroanilide (BAPA) as substrate according to Hamerstrand et al. [26].

\section{Statistical Analysis}

Statistical analyses were performed using computer program Statistical Packages for Social Science [27] and values compared with each other using one-way analysis of variance [ANOVA].

\section{Results}

The major chemical components of raw and treated soy flour were obtained at Table 1. It is evident that contents of raw soy flour not significantly affected by $\gamma$-irradiation at both dose $5 \& 10 \mathrm{KGy}$, extrusion and by the combination of irradiation and extrusion except the moisture content was significantly decreased under the effect of extrusion.

Results in Figure 1 showed the amino acid contents of raw and treated soy flour. The most abundant essential amino acids of raw soy flour were leucine, histidine, lysine and phenylalanine.

Arginine, aspartate, proline and glutamate were the most abundant nonessential amino acids of raw flour. In case of $\gamma$-irradiation, extrusion and irradiation+extrusion, all essential amino acids were increased by different values while histidine was slightly decreased in all treated soy flour except in extruded flour its value was slightly increased. However, all nonessential amino acids were aroused by the applying treatments on raw soy flour, but only proline was decreased, as well as the amount of serine was increased by $\gamma$-irradiation ( $5 \mathrm{KGy}$ ). In addition, cysteine not found in the raw flour but it was observed in all treated samples by different amount.

Raw soy flour contains unsaturated fatty acids oleic (47.99\%) of total identified fatty acids, palmitic (37.11\%) and stearic (14.90\%) as saturated fatty acid of total identified fatty acids. The total Saturated Fatty Acids (SFA), total UnSaturated Fatty Acids (USFA) and Unsaturated to Saturated ratio (U/S ratio) was $52.01 \%, 47.99 \%$ and 0.92 respectively. It can be seen from the result that, the percentage of palmitic (C16:0), stearic (C18:0) and oleic (C18:1) of raw flour were declined by $\gamma$-irradiation at 5 and $10 \mathrm{KGy}$ or/and extrusion.

Whereas, some fatty acids were observed by using the above mentioned treatments, such as linoleic acid (C18:2). Unsaturated to saturated ratio (U/S ratio) was changed by $\gamma$-irradiation at 5 and 10 KGy or/and extrusion to $0.99,1.27,3.60,1.77$ and 1.51, respectively (Figure 2).

Figure 3 showed the different mean value of 13 phenolic compounds in the raw and treated soybean flour. The main content of phenolic compounds of raw soy flour was pyrogallol, syringic, catachin and vanillic acid. Both of catachin and P-benzoic were increased under the effect of $\gamma$-irradiation, extrusion and the combination of both while these processing methods reduced pyrogallo, gallic and syringic acid.

As shown in Figure 4, the total phenol of raw soy flour $(7.25 \mathrm{mg} / \mathrm{g})$ was significantly increased by gamma irradiation at dose level $(5 \&$
Essential amino acids
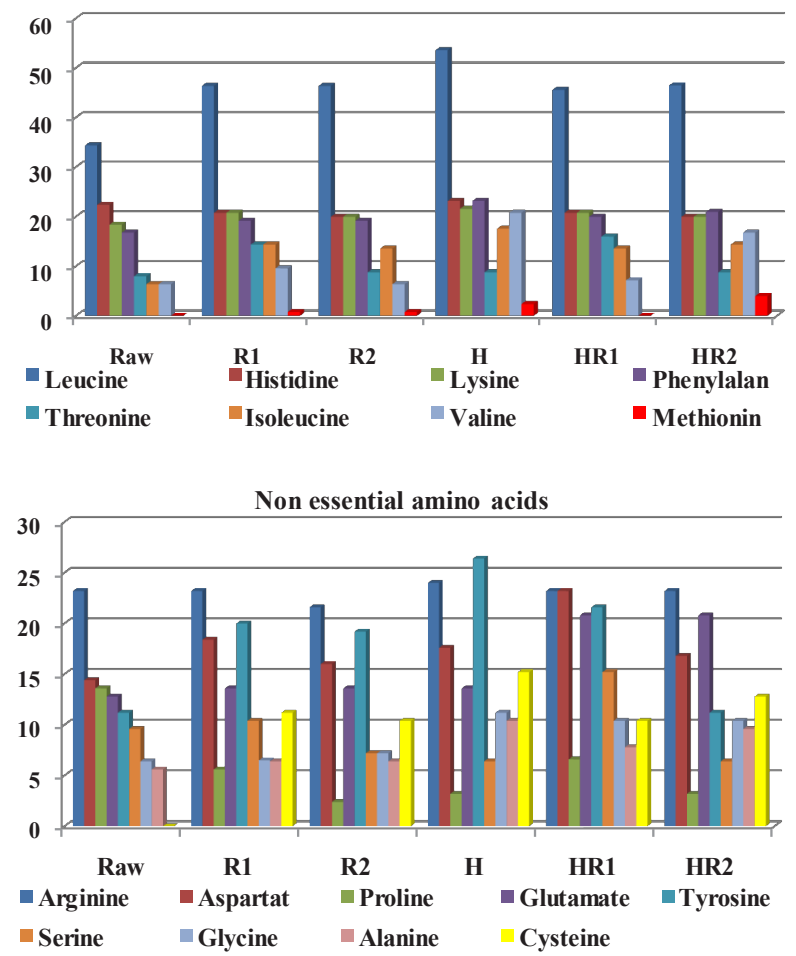

Figure 1: Effects of $y$-irradiation or/and extrusion on amino acid contents of soy flour.

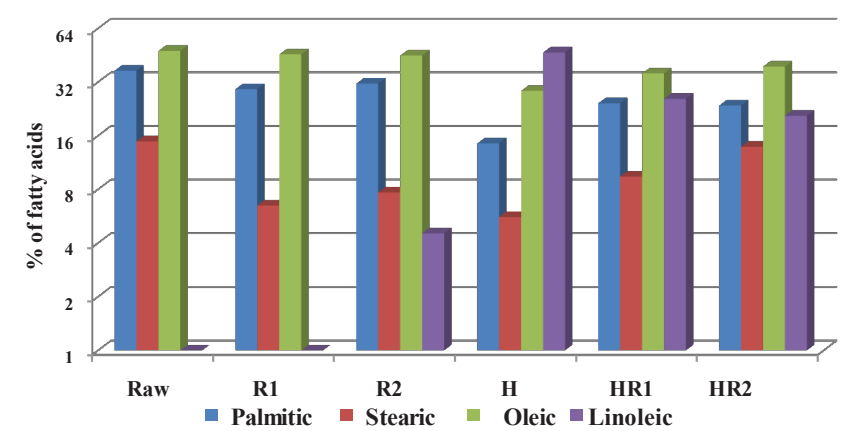

Figure 2: Effects of $y$-irradiation or/and extrusion on some fatty acid contents of soy flour (\%).

$10 \mathrm{KGy}$ ) to $9.6 \mathrm{mg} / \mathrm{g}$ and $10.5 \mathrm{mg} / \mathrm{g}$ and by irradiation (5 \& $10 \mathrm{KGy}$ ) and extrusion to 9.5 and $10 \mathrm{mg} / \mathrm{g}$, respectively. While the extrusion significantly decreased the total phenols to $6.5 \mathrm{mg} / \mathrm{g}$

The results observed in table 2 summarized the mean values of Tannin (TN), phytic Acid (PA) and trypsin inhibitor of raw and processed soy flour. A significant reduction was noticed in values of these antinutritional factors by processing of raw sample and the highest reduction was observed in irradiated (10 KGy)+extruded soy flour.

\section{Discussion}

Soybean and its products are economically valued because their 


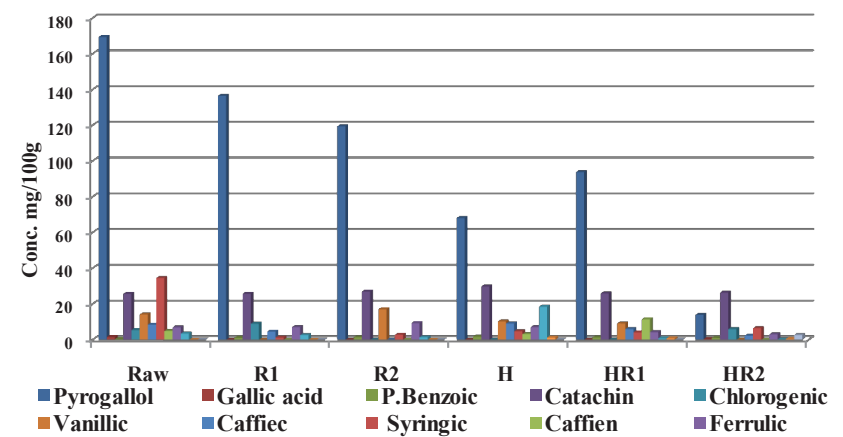

Figure 3: Effects of $\mathrm{Y}$-irradiation or/and extrusion on some phenolic compounds of soy flour.

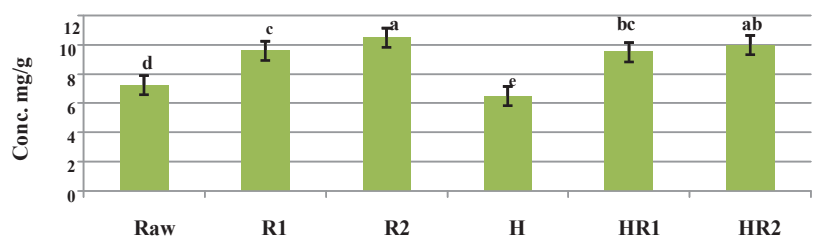

Figure 4: Effects of $\mathrm{Y}$-irradiation or/and extrusion on total phenols of soy flour.

\begin{tabular}{|c|c|c|c|c|c|c|c|}
\hline Treatment & Moisture & Ash & Fat & Fiber & \begin{tabular}{|l|} 
Crude \\
protein
\end{tabular} & NFE & $\begin{array}{l}\text { Dray } \\
\text { matter }\end{array}$ \\
\hline Raw & $\begin{array}{l}6.40 \\
\pm 0.057^{a}\end{array}$ & $\begin{array}{l}6.50 \\
\pm 0.057^{a}\end{array}$ & $\begin{array}{l}20.76 \\
\pm 0.33^{a}\end{array}$ & $\begin{array}{l}6.30 \\
\pm 0.057^{a}\end{array}$ & $\begin{array}{l}43.60 \\
\pm 0.15^{a}\end{array}$ & $\begin{array}{l}16.53 \\
\pm 0.33^{a}\end{array}$ & $\begin{array}{l}93.60 \\
\pm 0.057^{c}\end{array}$ \\
\hline$R_{1}$ & $\begin{array}{l}6.40 \\
\pm 0.057^{a}\end{array}$ & $\begin{array}{l}6.10 \\
\pm 0.057^{a}\end{array}$ & $\begin{array}{l}20.33 \\
\pm 0.33^{a}\end{array}$ & $\begin{array}{l}6.23 \\
\pm 0.033^{a}\end{array}$ & $\begin{array}{l}43.50 \\
\pm 0.06^{a}\end{array}$ & $\begin{array}{l}17.43 \\
\pm 0.29^{a}\end{array}$ & $\begin{array}{l}93.60 \\
\pm 0.057^{\circ}\end{array}$ \\
\hline$R_{2}$ & $\begin{array}{l}6.47 \\
\pm 0.033^{a}\end{array}$ & $\begin{array}{l}6.30 \\
\pm 0.057^{a}\end{array}$ & $\begin{array}{l}20.67 \\
\pm 0.33^{a}\end{array}$ & $\begin{array}{l}6.17 \\
\pm 0.057^{a}\end{array}$ & $\begin{array}{l}43.46 \\
\pm 0.14^{a}\end{array}$ & $\begin{array}{l}16.83 \\
\pm 0.40^{\mathrm{a}}\end{array}$ & $\begin{array}{l}93.53 \\
\pm 0.033^{c}\end{array}$ \\
\hline H & $\begin{array}{l}4.70 \\
\pm 0.057^{b}\end{array}$ & $\begin{array}{l}6.50 \\
\pm 0.057^{a}\end{array}$ & $\begin{array}{l}22.00 \\
\pm 0.57^{a}\end{array}$ & $\begin{array}{l}6.20 \\
\pm 0.033^{a}\end{array}$ & $\begin{array}{l}43.43 \\
\pm 0.08^{a}\end{array}$ & $\begin{array}{l}17.17 \\
\pm 0.63^{a}\end{array}$ & $\begin{array}{l}95.30 \\
\pm 0.057^{a}\end{array}$ \\
\hline $\mathrm{HR}_{1}$ & $\begin{array}{l}4.60 \\
\pm 0.057^{b}\end{array}$ & $\begin{array}{l}6.13 \\
\pm 0.033^{a}\end{array}$ & $\begin{array}{l}21 \\
\pm 0.57^{\mathrm{a}}\end{array}$ & $\begin{array}{l}6.13 \\
\pm 0.033^{a}\end{array}$ & $\begin{array}{l}43.36 \\
\pm 0.06^{a}\end{array}$ & $\begin{array}{l}18.77 \\
\pm 0.63^{a}\end{array}$ & $\begin{array}{l}95.4 \\
\pm 0.057^{a}\end{array}$ \\
\hline $\mathrm{HR}_{2}$ & $\begin{array}{l}4.87 \\
\pm 0.057^{b}\end{array}$ & $\begin{array}{l}6.23 \\
\pm 0.033^{a}\end{array}$ & $\begin{array}{l}20.76 \\
\pm 0.33^{a}\end{array}$ & $\begin{array}{l}6.07 \\
\pm 0.033^{a}\end{array}$ & $\begin{array}{l}43.36 \\
\pm 0.03 a\end{array}$ & $\begin{array}{l}18.61 \\
\pm 0.45^{a}\end{array}$ & $\begin{array}{l}94.13 \\
\pm 0.033^{b}\end{array}$ \\
\hline $\begin{array}{l}\text { Probabil- } \\
\text { ity }\end{array}$ & 0.0001 & 0.0763 & 0.2260 & 0.2006 & 0.5880 & 0.7707 & 0.0001 \\
\hline
\end{tabular}

$a, b, c, \ldots$. Means within same column followed by different letters are significantly different at $(P<0.05)$. Values are means of three replicates $( \pm S E)$.

$\mathrm{Raw} \rightarrow$ raw soy flour.

$\mathrm{R} 1 \rightarrow$ irradiated at dose $5 \mathrm{KGy} . \mathrm{R} 2 \rightarrow$ irradiated at dose $10 \mathrm{KGy}, \mathrm{H} \rightarrow$ extruded

$\mathrm{HR} 1 \rightarrow$ irradiated $(5 \mathrm{kGY})+$ Extruded. HR2 $\rightarrow$ irradiated $(10 \mathrm{KGY})+$ Extruded $\mathrm{NFE} \rightarrow$ Nitrogen Free Extract.

Table 1: Effects of $y$-irradiation, extrusion and their combinations on the chemical composition of soybean flour $(\%)$.

nutrient and phytochemical characteristics, which also classifies it as a food of high nutritional value and functional claims. Also, they contain several antinutritional factors, which could limit their consumption content and removal of these undesirable components is essential to improve the nutritional quality of soy [9].

In this study, the results of raw soy flour chemical composition were in line with Khan et al. [28], who analyzed soy and observed that moisture $(6.27 \%)$, protein $(41.56 \%)$, crude fat $(23.68 \%)$, crude fiber (6.825) and ash (4.54\%). The results confirmed that these chemical compositions were not significantly affected by $\gamma$-irradiation at both dose 5 \& 10 KGy which in agreement with El-Niely [29] and that can be attributed to the relatively limited amount of water content of soy flour,

\begin{tabular}{|l|l|l|l|}
\hline Treatment & Tannic acid $\mathbf{~ m g / g}$ & Phytic acid $\mathbf{~ m g / g}$ & $\begin{array}{l}\text { Trypsin inhibitor } \\
\text { IU/g }\end{array}$ \\
\hline Raw & $\begin{array}{l}0.46 \\
\pm 0.018^{\mathrm{a}}\end{array}$ & $\begin{array}{l}5.23 \\
\pm 0.088^{\mathrm{a}}\end{array}$ & $\begin{array}{l}75.37 \\
\pm 1.01^{\mathrm{a}}\end{array}$ \\
\hline $\mathbf{R}_{\mathbf{1}}$ & $\begin{array}{l}0.32 \\
\pm 0.011^{\mathrm{b}}\end{array}$ & $\begin{array}{l}4.53 \\
\pm 0.176^{\mathrm{b}}\end{array}$ & $\begin{array}{l}65.60 \\
\pm 0.70^{\mathrm{b}}\end{array}$ \\
\hline $\mathbf{R}_{2}$ & 0.26 & 4.43 & 49.47 \\
& $\pm 0.008 \mathrm{~b}^{\mathrm{c}}$ & $\pm 0.088^{\mathrm{b}}$ & $\pm 0.41^{\mathrm{c}}$ \\
\hline $\mathbf{H}$ & 0.23 & 3.40 & 32.87 \\
& $\pm 0.005 \mathrm{~b}^{\mathrm{c}}$ & $\pm 0.057^{\mathrm{c}}$ & $\pm 0.32^{\mathrm{d}}$ \\
\hline $\mathbf{H R}_{\mathbf{1}}$ & 0.21 & 3.27 & 29.23 \\
& $\pm 0.005 \mathrm{~b}^{\mathrm{c}}$ & $\pm 0.033^{\mathrm{c}}$ & $\pm 0.20^{\mathrm{d}}$ \\
\hline $\mathbf{H R}_{\mathbf{2}}$ & 0.18 & 3.17 & 28.03 \\
$\pm 0.12^{\mathrm{d}}$ & $\pm 0.033^{\mathrm{c}}$ & $\mathbf{0 . 0 0 0 3}$ \\
\hline Probability & $\mathbf{0 . 0 1 3 0}$ & $\mathbf{0 . 0 0 2 0}$ & $\mathbf{0 . 0 0 0 3}$ \\
\hline
\end{tabular}

$a, b, c, \ldots$. Means within same column followed by different letters are significantly different at $(P<0.05)$. Values are means of three replicates $( \pm S E)$.

Raw $\rightarrow$ raw soy flour.

$\mathrm{R} 1 \rightarrow$ irradiated at dose $5 \mathrm{KGy} . \mathrm{R} 2 \rightarrow$ irradiated at dose $10 \mathrm{KGy} . \mathrm{H} \rightarrow$ extruded.

$\mathrm{HR} 1 \rightarrow$ irradiated $(5 \mathrm{kGY})+$ Extruded. HR2 $\rightarrow$ irradiated $(10 \mathrm{KGY})+$ Extruded $\mathrm{NFE} \rightarrow$ Nitrogen Free Extract.

Table 2: Effects of $y$-irradiation, extrusion and their combinations on antinutritional factors of soy flour.

so it would not be easily to be radiolyzed by irradiation to produce enough free radicals that could induce significant changes in gross composition of this material. Moreover, the crude protein and fat in a complex matrix of foodstuffs have been reported to be more resistant to radiation than in the pure state [30]. On the other hand, only the moisture content was decreased by extrusion processing and that may be due to the release of water during extrusion processing produced extrudates with lower moisture content than raw flour. Nearly the same results were reported by Alonso et al. [31] who observed that extrusion processing at high temperature and short time resulted in water and volatile compounds evaporation and that cause release of water and decrease in moisture content of seeds.

It was necessary in the present investigation undertaking amino acid analysis to asses if any alteration has been occurred in the protein quality due to $\gamma$-irradiation exposure and extrusion treatment. The results of amino acid analysis of both raw and treated soy flour obtained that some essential and non essential amino acids of treated soy flour had higher level than those of raw one. However, histidine was increased only in case of extrusion while serine was aroused by $\gamma$-irradiation at dose $5 \mathrm{KGy}$ as well as proline value was declined under the effect of all different treatments. In addition, both of cysteine and methionine was not observed in the raw flour but appeared by applying the different processing methods. The results of amino acids of $\gamma$-irradiated soy flour were in agreement with those found by Abd-Elkalik et al. [32]. The changes in the concentration of amino acids induced by irradiation may probably be due to free radicals that might be formed in association with splitting of the peptide bonds, deamination and decarboxylation reactions of amino acids followed by chains of chemical reactions forming other new radicals [33]. Similarly, the extrusion cooking has some unique features compared to other heat processes and is able to break covalent bonds in biopolymers, and the intense structural disruption and mixing facilitate reactions otherwise limited by diffusion of reactants and products $[34,35]$.

In regard to the fatty acid profile of raw and processed soy flour, the results indicated that oleic acid (C18:1) was the most abundant fatty acid in raw soybean followed by palmitic (C16:0) and stearic (C18:0). It was observed that $\gamma$-irradiation at different dose levels (5 \& $10 \mathrm{KGy}$ ) caused different changes in the fatty acid composition which may be due to molecular structure change in fatty acids, formation of free radicals 
induced by gamma irradiation [36]. Al-Kahtani et al. [37] observed that irradiation at 1.5-10 KGy caused a decrease in some fatty acids (C14:0, C16:0 and C16:1).Maxwell and Rady [38] reported an increase in oleic acid with increasing doses of gamma irradiation. However, Hafez et al. [39] did not find changes in the fatty acids (C16:0, C18:1 and C18:2) of soybeans at different radiation doses $(1,5,10,20,40,60,80$ and 100 KGy). Similarly, Byun et al. [40] showed no significant changes in the fatty acid composition, and trans fatty acids content of soybean oil extracted from gamma irradiated soybean (0-10 kGy).

Additionally, the data in the present study obtained that extrusion processing and irradiation + extrusion increased the total Unsaturated Fatty Acid (USF) as well as these processing methods resulted in appearance of linoleic acid (C18:2). Rokey and Plattner [41] observed that fatty acid composition can be affected during extrusion as a result of hydrogenation, isomerization, polymerization and lipid oxidation. Also, Žilić et al. [42] reported that depending on the temperature and applied heat treatments, the content of linoleic and oleic fatty acid oscillated.

Results in the study obtained that treatment of soy flour with gamma irradiation (5 \& $10 \mathrm{KGy}$ ) caused different changes in phenolic contents by increasing the amount of P-benzoic and ferrulic and decreasing of pyrogallol, syringic and chrisin. Villavicencio et al. [43] presented higher contents of phenolic compounds in irradiated samples when compared with raw samples and attributed this result due to decomposition of some large insoluble phenolic compounds into small soluble phenolic molecules and may also be beneficial for the antioxidant properties of the plant seeds.

In the effect of extrusion, the contents of selected phenolic compounds before and after extrusion cannot give univocal conclusions. In this study, the observed increase in some free phenolic compounds during extrusion could be due to the increased release of these bioactive compounds from the matrix due to extrusion thus accessible in the extraction [44]. In addition, reduction of total phenols during extrusion could be attributed to thermal degradation and denaturation, changes in chemical reactivity or to formation of insoluble complexes during heating [45].

The values of some antinutritional factors for both raw and processed soy flour demonstrated that the irradiation (5 \& $10 \mathrm{KGy}$ ) or/and extrusion processing reduced the tannin content, phytic acid and trypsin inhibitor concentration in soybean flour. Villavicencio et al. [43] and Mechi et al. [46] reported that gamma radiation promoted reduction in the tannin contents as the radiation dose increased until a limited dose. The mechanism of gamma irradiation action on tannin has been related to generation of the hydroxyl and superoxide anion radicals [47], but mode of electron beam action on tannins has not been demonstrated [48]. The effect of extrusion on tannin was studied by El-hady and Habiba [49] and they have reported significant reduction in tannin content after extruding legume seeds at different moisture contents. Also, Alonso et al. [50] studied the effects of extrusion and conventional processing methods on protein and antinutritional factors and they found varietal changes in the tannin contents, and extrusion was most effective in reducing tannins than the other processes.

The elimination of phytic acid by $\gamma$-irradiation is probably due to chemical degradation of phytate to lower inositol phosphates and inositol, by the action of free radicals, which have lower chelating power, or cleavage of the phytate ring itself [51,52]. Authors suggested that during extrusion inositol hexaphosphate could have been hydrolyzed to lower molecular weight forms resulted in decreasing the phytic content $[53,54]$.
Inactivation of trypsin inhibitor in irradiated samples could be attributed to the destruction of disulphide (-S-S-) groups [55,56]. AbuTarboush [57] found reduction of $34.9 \%$ on the trypsin inhibitory activity in soybean flour radiated with $10 \mathrm{kGy}$. The author attributed this reduction to the breakage of the trypsin inhibitory structure with the radiation treatment. Farag et al. [58] observed an increase in the inactivation level with increase in the doses used (41.8\%, 56.3\%, $62.7 \%$ and $72.5 \%$ of loss in the trypsin inhibitory activity) for doses of 5,15 , 30 and $60 \mathrm{kGy}$, respectively.

Thermal treatment of ANFs had been reported to be a valuable process for the inactivation of TIA. The reduction in TIA following extrusion by up to $90 \%$ was reported in the literature for other foods particularly mungbean, cowpea and blends with other crops [59].

\section{Conclusion}

In conclusion, the results obtained in this study suggest that irradiation or/and extrusion may be chosen as beneficial methods not only in reducing phytic acid, tannins and trypsin inhibitors as antinutritional factors but also in increasing the total phenolic contents of the raw flour. However, the nutritional attributes i.e. fat, protein, fiber and ash of the soybean flour remained constant after gamma irradiation exposure or/and extrusion processing.

\section{References}

1. Tharanathan RN, Mahadevamma S (2003) Grain legumes: a boon to human nutrition. Food Sci Technol 14: 507-518.

2. Jezierny D, Mosenthin R, Sauer N, Roth S, Piepho H-P, et al. (2011) Chemica composition and standardised ileal digestibilities of crude protein and amino acids in grain legumes for growing pigs, Livestock Sci 138: 229-243.

3. de Almeida Costa GE, da Silva Queiroz-Monici K, Reis SMPM, de Oliveira AC (2006) Chemical composition, dietary fibre and resistant starch contents of raw and cooked pea, common bean, chickpea and lentil legumes. Food Chem 94: 327-330.

4. Krishnan HB (2000) Biochemistry and molecular biology of soybean seed storage proteins. Journal of New Seeds 2: 1-25.

5. Krishnan HB (2005) Engineering soybean for enhanced sulfur amino acid content. Crop Sci 45: 454-461.

6. Aduloju MO, Mahamood J, Abayomi YA (2009) Evaluation of soybean [Glycine $\max (\mathrm{L})$ Merrill] genotypes for adaptability to a southern Guinea savanna environment with and without $P$ fertilizer application in north central Nigeria. Afr J Agric Res 4: 556-563.

7. Lee SJ, Ahn JK, Khanh TD, Chun SC, Kim SL, et al.(2007) Comparison of Isoflavone Concentrations in Soybean (Glycine max (L.) Merrill) Sprouts Grown under Two Different Light Conditions. J Agric Food Chem 55: 9415-9421.

8. Almeida DT, Greiner R, Furtunado DM, Trigueiro INS, Araŭjo MP (2008) Content of some antinutritional factors in bean cultivars frequently consumed in Brazil. International Journal of Food Science and Technology 43: 243-249.

9. Mubarak $A E$ (2005) Nutritional composition and antinutritional factors of mung bean seeds (Phaseolus aureus) as affected by some home traditional processes. Food Chem 89: 489-495.

10. Khattab RY, Arntfield SD, Nyachoti CM (2009) Nutritional quality of legume seeds as affected by some physical treatments, Part 1: Protein quality evaluation. LWT- Food Science and Technol 42: 1107-1112.

11. Pednekar M, Das A, Rajalakshmi V, Sharma A (2010) Radiation processing and functional properties of soybean (Glycine max). Food Eng 79: 490-494.

12. Dixit AK, Kumar V, Manjaya JG, Rani A, Bhatnagar D (2011) Effect of gamma irradiation on lipoxygenases, trypsin inhibitor, raffinose family oligosaccharides and nutritional factors of different seed coat colored soybean (Glycine max L.). Radiat Phys Chem 80: 597-603.

13. Gu L, House SE, Rooney LW, Prior RL (2008) Sorghum extrusion increase bioavailability of catechins in weanling pigs. J Agri Food Chem 56: 1283-1288.

14. Shawrang P, Nikkhah A, Zare-Shahneh A, Sadeghi AA, Raisali G, et al.(2007) 
Citation: Hamza RG, Afifi S, Abdel-Ghaffar ARB, Borai IH (2012) Effect of Gamma-Irradiation or/and Extrusion on the Nutritional Value of Soy Flour. Biochem Anal Biochem 1:118. doi:10.4172/2161-1009.1000118

Effects of gamma irradiation on protein degradation of soybean meal in the rumen. Anim Feed Sci Technol 134: 140-151.

15. Shawrang P, Nikkhah A, Zare-Shahneh A, Sadeghi AA, Raisali G, et al.(2008) Effects of gamma irradiation on chemical composition and ruminal protein degradation of canola meal. Radiat Phys Chem 77: 918-922.

16. Dixit AK, Bhatnagar D, Kumar V, Rani A, Manjaya JG, et al. (2010) Gamma irradiation induced enhancement in isoflavones, total phenol, anthocyanin and antioxidant properties of varying seed coat colored soybean. J Agric Food Chem 58: 4298-4302.

17. Singh J, Dartois A, Kaur L (2010) Starch digestibility in food matrix: a review. Trends Food Sci Technol 21: 168-180.

18. Zhu LJ, Shukri R, Stonestreet NJ, Alavi S, Dogan H, et al. (2010) Mechanical and microstructural properties of soy protein-high amylose corn starch extrudates in relation to physiochemical changes of starch during extrusion. $J$ Food Eng 100: 232-238.

19. A.O.A.C (2005) Official Methods of Analysis of AOAC International (18th Edn), Revision 1, Washington D.C, U.S.A.

20. Suzanna Nielson S (1998) Food analysis. (2ndedn), An Aspen puplication, Aspen publishers inc., Gaithersburg, Mary Lan. pp.34.

21. Nollet Leo ML (1996) Hand book of food analysis, Marcel Dekkes, Inc., Vol.1, Physical characterization and nutrient analysis, chapter 7, pp.210.

22. Gao X, Bjork L, Trajkovski V, Uggla M (2000) Evaluation of antioxidant activities of rosehip ethanol extracts in different test systems. J Sci Food Agric 80: 2021 $-2027$

23. Goupy P, Hugues M, Boivin P, Amiot MJ (1999) Antioxidant composition and activity of barley (Hordeum vulgare) and malt extracts and of isolated phenolic compounds. J Sci Food Agric 79: 1625-1634

24. Burns RE (1971) Method for estimation of tannin in grain sorghum. Agron $J$ 63: $511-512$.

25. Wheeler EL, Ferrel RE (1971) A method for phytic acid determination in wheat and wheat fractions. Cereal Chem 48: 312-320.

26. Hamerstrand GE, Black LT, Glover JD (1981) Trypsin inhibitors in soy products: modification of the standard analytical procedure. Cereal Chem 58:42-45.

27. SPSS (1998) Statistical Package for Social Sciences. Computer Software, Ver. 10,SPSS Company, London, UK.

28. Khan MI, Anjum FM, Hussain S, Tariq MT (2005) Effect of soy flour supplementation on mineral and phytate contents of unleavened flat bread (chapatis). Nutr Food Sci 35: 163-168

29. El-Niely HFG (2007) Effect of radiation processing on antinutrients, in-vitro protein digestibility and protein efficiency ratio bioassay of legume seeds. Radiat Phys Chem 76: 1050-1057.

30. Diehl JF, Scherz H (1975) Estimation of radiolytic products as a basis for evaluating the wholesomeness of irradiated foods. Int J Appl Radiat Isot 26 : 499-501.

31. Alonso R, Rubio LA, Muzquiz M, Marzo F (2001) The effect of extrusion cooking on mineral bioavailability in pea and kidney bean seed meals. Anim Feed Sci Technol 94: 1-13.

32. Abd-ELkalik K, El-Demerdash HM, Mekkawy SH (2010) Evaluation of chemical changes in some soybean mutants induced by gamma irradiation., J Rad Res Appl Sci. 3: 149-163.

33. Elias PS, Cohen AJ (1977) Radiation chemistry of major food components. Elsevier Biomedical press, Amsterdam, Netherlands.

34. Colona P, Tayeb J, Mercier C (1989) Extrusion cooking of starch and starchy products. Extrusion Cooking. St. Paul, MN: AACC Inc. 247-319.

35. Iwe MO, van Zuilichem DJ, Ngoddy PO, Lammers W (2001) Amino acid and protein dispersibility index (PDli) of mixtures of extruded soy and sweet potato flours. Lebensm-Wiss U.-Technol 34: 71-75.

36. Arici M, Colak FA, Gecgel Ü (2007) Effect of gamma radiation on microbiologica and oil properties of black cumin (Nigella sativa L.) Grasas Y Aceites 58: 339343.

37. Al-Kahtani HA, Abu-Tarboush HM, Bajaber AS, Atia M, Abou-Arab AA, et al.(1996) Chemical changes after irradiation and post-irradiation storage in Tilapia and Spanish mackerel. J Food Sci 61: 729-733.
38. Maxwell JR, Rady AJ (1989) Effect of gamma irradiation at various temperatures on air and vacuum packed chicken tissues II. Fatty acid profiles of neutral and polar lipids separated from muscle and skin irradiated at $2-5^{\circ} \mathrm{C}$. Radiat Phys Chem 34: 791-796.

39. Hafez YS, Mohamed Al, Singh G, Hewedy FM (1985) Effects of gamma irradiaton on proteins and fatty acids of soybean. J Food Sci 50: $1271-1274$

40. Byun MW, Kang IJ, Kwon JH, Hayashi Y, Mori T (1996) Physicochemical properties of soybean oil extracted from $y$-irradiated soybeans. Radiat Phys Chem 47: 301-304

41. Rokey G, Plattner B (1995) Process description. Pet food production. Wenger Mfg Inc., Sabetha, KS USA, pp.1-18.

42. Žilić SM, Šobajić SS, Mladenović-Drinić SD, Kresović BJ, Vasić MG (2010) Effects of heat processing on soya bean fatty acids content and the lipoxygenase activity. J Agri Sci 55: 55-64.

43. Villavicencio ALCH, Mancini-Filho J, Delincée H, Greiner R (2000) Effect of irradiation on anti-nutrients (total phenolics, tannins and phytate) in Brazilian beans. Radiat Phys Chem 57: 289-293.

44. Zieliński H, Michalska A, Piskuła MK, Kozłowska H (2006) Antioxidants in thermally treated buckwheat groats. Mol Nutr Food Res 50: 824-832.

45. Siddhuraju P, Becker K (2001) Effect of various domestic processing methods on antinutrients and in vitro protein and starch digestibility of two indigenous varieties of Indian tribal Pulse, Mucuna pruriens var. utilis. J Agric Food Chem 49: 3058- 3067.

46. Mechi R, Canniatti-Brazaca SG, Arthur V (2005) Avaliacão quǐmica, nutriciona e fatores antinutricionais do feijão preto (Phaseolus vulgaris L.) irradiado Cienc Technol Aliment 25: 109-114.

47. Riley PA (1994) Free radicals in biology: oxidative stress and the effects of ionizing radiation. Int J Radiat Biol 65: 27-33.

48. Shawrang P, Sadeghi AA, Behgar M, Zareshahi H, Shahhoseini G (2011) Study of chemical compositions, anti-nutritional contents and digestibility of electron beam irradiated sorghum grains. Food Chem 125: 376-379.

49. El-hady EAA, Habiba RA (2003) Effect of soaking and extrusion conditions on antinutrients and protein digestibility of legume seeds. LWT-Food Sci Technol 36: $285-293$

50. Alonso R, Grant G, Dewey P, Marzo F (2000) Nutritional assessment in vitro and in vivo of raw and extruded peas (Pisum sativum L.). J Agric Food Chem 48: $2286-2290$.

51. de Boland AR, Garner GB, O'Dell BL (1975) Identification and properties of phytate in cereal grains and oilseed products. J Agric Food Chem 23: 1186 -1189 .

52. Siddhuraju P, Makkar HPS, Becker K (2002) The effect of ionising radiation on antinutritional factors and the nutritional value of plant materials with reference to human and animal food. Food Chem 78: 187-205.

53. Alonso R, Aguirre A, Marzo F (2000) Effects of extrusion and traditional processing methods on antinutrients and in vitro digestibility of protein and starch in faba and kidney beans. Food Chem 68: 159-165.

54. Anton AA, Fulcher GR, Arntfield DS (2009) Physical and nutritional impact of fortification of corn starch-based extruded snacks with common bean (Phaseolus vulgaris L.) flour: Effects of bean addition and extrusion cooking. Food Chem 113: 989-996.

55. El-Morsi SA, Fawzay AM (1992) Effect of gamma irradiation on trypsin inhibitor and subunit structure of proteins in field bean (Vicia faba $L$ ) seeds during germination. Minia J of Agric \& Res Dev 14: 849-871.

56. Tresina PS, Mohan VR (2012) Physico-chemical and antinutritional attributes of gamma irradiated Vigna unguiculata (L.) Walp. subsp. unguiculata seeds. In Food Res J 19: 639-646.

57. Abu-Tarboush HM (1998) Irradiation inactivation of some antinutritional factors in plant seeds. J Agric Food Chem 46: 2698-2702.

58. Farag RS, Hewedi FM, Abu -Raiia SH, El-Baroty GS (1992) Comparative study on the deterioration of oils by microwave and conventional heating. J Food Prot 55: $722-727$

59. Iwe MO, Ngoddy PO (2000) Effect of extrusion on trypsin inhibitor contents of soy-sweet potato mixtures. J Food Process Preserv 24: 453 -463. 